\title{
Optimization of ethanol fermentation from discarded carrots using immobilized Saccharomyces cerevisiae
}

\author{
Adriana L. Clementz $\cdot$ Nora R. Aimaretti • \\ Debora Manuale $\cdot$ Agustín Codevilla • \\ Juan C. Yori
}

Received: 30 September 2014/Accepted: 9 December 2014/Published online: 18 December 2014

(C) The Author(s) 2014. This article is published with open access at Springerlink.com

\begin{abstract}
Discarded carrots are a valuable source of biomass amenable for valorization. Their use as raw material for ethanol production by fermentation, using yeasts immobilized in Calcium alginate, was proposed. The biocatalyst immobilization method, the existence of internal and external mass transfer limitations, the effect of the initial $\mathrm{pH}$ and the reuse of immobilized yeasts were particularly evaluated. Results indicate that beads made with a $2 \%$ solution of Sodium alginate and a $30 \%$ solution of Saccharomyces cerevisiae were strong enough to allow an efficient nutrient transfer into the matrix and to prevent cell leaking. A stirring rate of $200 \mathrm{rpm}$ was needed to avoid external mass transfer limitations. These beads were used in three successive fermentations. An initial $\mathrm{pH}$ of 5.5 reached the best fermentation parameters. Non-enriched, non-sterile carrot must was fermented through immobilized yeasts; and values of ethanol concentration $\left(29.9 \mathrm{~g} \mathrm{~L}^{-1}\right)$, $Y_{\mathrm{p} / \mathrm{s}}\left(0.409 \mathrm{~g} \mathrm{~g}^{-1}\right)$, and productivity $\left(7.45 \mathrm{~g} \mathrm{~L}^{-1} \mathrm{~h}^{-1}\right)$ were obtained. These values were similar to those registered when free cells were used.
\end{abstract}

Keywords Bioethanol - Carrot discard - Immobilization . Calcium alginate bead $\cdot$ Reuse

\footnotetext{
A. L. Clementz · N. R. Aimaretti · D. Manuale · J. C. Yori ( Facultad de Ingeniería Química, Instituto de Investigaciones en Catálisis y Petroquímica, Universidad Nacional del Litoral, CONICET, Santiago del Estero 2654, 3000 Santa Fe, Provincia de Santa Fe, Argentina

e-mail: jyori@fiq.unl.edu.ar

N. R. Aimaretti · A. Codevilla

Laboratorio de Investigaciones Aplicadas, Facultad de Química, Universidad del Centro Educativo Latinoamericano, Av Pellegrini 1332, 2000 Rosario, Argentina
}

\section{Introduction}

Nowadays, the conversion of biomass into biofuels represents a significant economic option [1]. Ethanol is one of the most important renewable fuels contributing to the reduction of negative environmental impacts generated by the worldwide utilization of fossil fuels [2].

Bioethanol is generally produced from raw materials containing fermentable sugars, such as sugar cane, sweet sorghum, beet molasses, corn, wheat, etc. [3, 4]. However, the current focus on ethanol production is the conversion from non-edible sources or wastes-such as agricultural and forest residues-into second generation ethanol. It is the abundance and the low-cost of these raw materials that make them attractive as such [5].

In the Santa $\mathrm{Fe}$ region (Argentina), 50-100 tons of carrots-almost $30 \%$ of the total production-are discarded every day during the harvest time. Discards are generally made up of carrots that do not meet commercial standards with regard to size or shape, or whose economic value would not be enough to compensate for the harvesting costs [6]. Such a high percentage of discards is not exclusively seen in Argentina: similar values are found in other countries as well. In general, only $10 \%$ of total discards is used for animal consumption; the rest remains in the fields generating odors and causing land deterioration, which are the main agents producing a highly adverse environmental impact. As a consequence, reutilization of this type of discard is very important.

In previous papers [7, 8], it was concluded that the must extracted from discarded carrots could be used as raw material for ethanol fermentation in a stirred tank bioreactor using free cells of Saccharomyces cerevisiae as biocatalyst, with neither sterilization pretreatment nor addition of nutrients. It was also reported that the maximum productivity and ethanol yield 
were $6.2 \mathrm{~g} \mathrm{~L}^{-1} \mathrm{~h}^{-1}$ and $0.295 \mathrm{~g} \mathrm{~g}^{-1}$, respectively. Apart from the results, difficulties found in the purification of the fermented must (cell separation) were also highlighted. Some of them are the high costs of installation and microbial recycling, the high contamination risks, and the susceptibility of the microorganism to environmental variations [9]. These problems could be overcome using immobilized yeast. The most extensively studied method in cell immobilization is entrapment. This technique is based on the inclusion of cells within a rigid network to prevent cells from spreading into the reaction medium. Sodium alginate (Na-alginate) solutions form gels of Calcium alginate (Ca-alginate) in the presence of cations such as $\mathrm{Ca}^{2+}$ [10]. Immobilizing cells in alginate is simple, economic, and not toxic. Therefore, Ca-alginate is frequently used for immobilization because of the simplicity of the procedure to prepare the beads and the mild conditions required. Several reports indicating the use of this compound are available [11-14].

Although many works have been done on the production of ethanol immobilizing yeasts in Ca-alginate, in none of them have discarded carrots been used as raw material for fermentation.

The aim of this work was to learn the feasibility of producing second generation ethanol through the use of carrot discards, particularly through the immobilization of $S$. cerevisiae yeast in Ca-alginate as biocatalyst. The biocatalyst immobilization method, the existence of internal and external mass transfer limitations, the effect of the initial $\mathrm{pH}$ and the possible beads reuse were specifically studied.

\section{Materials and methods}

Raw material, handling and storage

Discarded carrots (Daucus carota) were collected in November and December 2012 from a packing shed in the Santa Fe area $\left(31^{\circ} 25^{\prime} \mathrm{S}, 60^{\circ} 20^{\prime} \mathrm{W}\right)$, Argentina. As for handling and storage, the method described by Aimaretti and Ybalo [7] was used.

\section{Carrot must}

Discarded carrots were selected leaving aside areas affected by microorganisms. Then, their juice was extracted by a continuous milling, compressing and filtering treatment. Particulates present in carrot juice were separated through centrifugation for $10 \mathrm{~min}$ at 3,500 rpm. The supernatant was named carrot must (CM) and its average sugar content was $89.8 \pm 1.2 \mathrm{~g} \mathrm{~L}^{-1}$ and its $\mathrm{pH}$ was $6.4 \pm 0.2$. CM was not subject to sterilization. To evaluate the effect of the initial $\mathrm{pH}$ value, this was adjusted by adding sulfuric acid.
Microorganism

Saccharomyces cerevisiae was provided by a local supplier (Dánica, Argentina) in the form of pressed yeast and it was reactivated directly in the carrot juice. Whole yeast cells were kept in a sterile container, without addition of nutrients, at $4{ }^{\circ} \mathrm{C}$ and saturation humidity, during six days [6].

Yeast immobilization method

For the immobilization of yeasts, two solutions were required: one consisting of living cells of $S$. cerevisiae in water (solution A), and another one consisting of $\mathrm{Na}$ alginate (Protanal LM 120 LS) in water (solution B). Both solutions were mixed together at equal volumes $\left(1: 1 \mathrm{v} \mathrm{v}^{-1}\right)$ and stirred until a homogeneous solution was visible. Then, with a micropipette, the solution was added dropwise to a $0.2 \mathrm{M} \mathrm{CaCl}_{2}$ solution prepared in a $0.05 \mathrm{M}$ sodium acetate buffer ( $\mathrm{pH}$ 5.6). Drops solidified in the form of beads and yeast cells were entrapped inside. Beads were kept in suspension for $30 \mathrm{~min}$ to harden. To remove calcium ion excess and free cells, beads were separated and washed with a $0.01 \mathrm{M}$ sodium acetate buffer of $\mathrm{pH} 5.6$ [15] and were used immediately after that, avoiding contact with oxygen. During the optimization of this method, three different concentration values of solution $\mathrm{A}-5,30$ and $60 \%\left(\mathrm{w} \mathrm{v}^{-1}\right)$ - , and four different concentration values of solution $\mathrm{B}-0.5,1.0,1.5$, and $2.0 \%\left(\mathrm{w} \mathrm{v}^{-1}\right)$-were used.

Bead diameter was modified using different pipette tips so as to obtain different drop sizes. The resulting bead diameter was measured with a micrometer. The concentration of living cells entrapped in Ca-alginate beads was determined by dissolving 100 beads in $30 \mathrm{~mL}$ of a $0.1 \mathrm{M}$ sodium citrate solution at room temperature, continuously stirring, and by quantifying with a Neubauer counting chamber with methylene blue stain [7].

To recycle the immobilized biocatalyst, fermented CM was filtered. Beads were returned to the reactor and the same amount of fresh $\mathrm{CM}$ at $30{ }^{\circ} \mathrm{C}$ was added, stirring the reaction medium, to start a new fermentation cycle.

\section{Fermentation conditions}

For ethanol fermentation studies, CM was used exactly as it was obtained, without any adjustment in sugar levels, addition of nutrients, or sterilization treatment. Newly prepared beads and CM were used in each test. Batch fermentation was performed at $30{ }^{\circ} \mathrm{C}$, in a $50 \mathrm{~mL}$ stirred tank bioreactor with controlled heating and stirring, built in the laboratory of UNL (Argentina). The fermentation progress was monitored by measuring the $\mathrm{CO}_{2}$ production with the aid of a gasometric probette. The stirring rate was controlled to always be $200 \mathrm{rpm}$ in most assays, exceptions 
being during the assessment of external mass transfer limitations. After fermentation was complete, samples were taken and centrifuged for $10 \mathrm{~min}$ at 5,000 rpm. The supernatant was transferred to sterile tubes for storage and it was kept at $-18{ }^{\circ} \mathrm{C}$. All experiments were performed in triplicates.

\section{Analytical methods}

\section{Sugar concentration}

The concentration of total sugar was measured by the 3.5dinitrosalicylic acid (DNS) method after acid hydrolysis $\left(1.2 \mathrm{M} \mathrm{HCl}\right.$ at $65{ }^{\circ} \mathrm{C}$ for $15 \mathrm{~min}$ ), neutralization with $1 \mathrm{M}$ $\mathrm{NaOH}$, and filtration [16].

\section{Ethanol concentration}

Ethanol concentration was measured by gas chromatography in a Shimadzu GC 2014 apparatus equipped with a ZB-wax capillary column. Isopropanol was used as internal standard. The column temperature was $40{ }^{\circ} \mathrm{C}$ (isothermal), the injector and the detector temperatures were $220^{\circ} \mathrm{C}$.

\section{Fermentation parameters}

The following fermentation parameters were calculated to compare the responses of different assays: (1) $Y_{\mathrm{p} / \mathrm{s}}$, ethanol yield per substrate, the ratio of total ethanol produced to the amount of consumed sugar, [ $\mathrm{g} \mathrm{g}^{-1}$ ]; (2) $Y_{\mathrm{p} / \mathrm{x}}$, ethanol yield per cell, the ratio of total ethanol produced to the total biomass $\left[\mathrm{g} \mathrm{g}^{-1}\right.$ ]; (3) Productivity, the ratio of total alcohol production to the total fermentation time $\left[\mathrm{g} \mathrm{L}^{-1} \mathrm{~h}^{-1}\right.$ ] [17]. In all instances, it is considered that the total time for fermentation was $4 \mathrm{~h}$.

\section{Scanning electron microscope}

A scanning electron microscope (SEM) (JEOL, JSM-35C), was used to observe the morphology of beads and cells of immobilized S. cerevisiae. Two samples of the beads were examined, before and after fermentation. The alginate beads were cut along the central axis and the resulting hemispheres were coated with gold in an argon atmosphere for further inspection using a microscope.

\section{Statistical analysis}

To examine the reproducibility of the experiment, three experimental runs of each batch test were carried out and measurements were performed in duplicates. The data were analyzed using the one-way ANOVA procedure of the SPSS software. Differences between means were detected using the Duncan's Multiple-Range Test. Data were considered significantly different when $P<0.05$.

\section{Results and discussion}

\section{Optimization of biocatalyst immobilization method}

An optimum immobilization matrix would be one having a structure rigid enough to retain the amount of cells required by the process, adequate mechanical properties, and a suitable porosity. The latter is needed to prevent diffusion problems, thus, allowing the free access of nutrients for cell metabolism. These requirements may prove to be controversial, so it is necessary to find a proper balance. Therefore, a study of the main variables affecting the properties of beads was performed.

\section{Effect of yeast concentration in solution A}

To determine the number of entrapped cells in each bead when yeast concentration was caused to vary, three tests with different yeast concentrations-5, 30 and $60 \%-$ were used. In all assays a concentration of $2 \% \mathrm{Na}$-alginate was used in solution B (see Section. "Yeast immobilization method"). The biocatalyst activity was also analyzed through these tests.

Table 1 shows the number of cells entrapped per bead, ethanol production, productivity and $Y_{\mathrm{p} / \mathrm{x}}$, employing 750 beads in each experiment. When yeast concentration in solution A was increased from 5 to $30 \%$, more cells were entrapped in the beads and a proportional increase in the fermentation rate was produced. Therefore, higher values of ethanol concentration and productivity were obtained; however, the corresponding values of $Y_{\mathrm{p} / \mathrm{x}}$ only differed by $5 \%$. This would indicate that virtually all entrapped cells participated in fermentation. Thus, a high level of inoculum was achieved, allowing the non-sterilized CM batch process $[7,8]$.

Conversely, when the concentration of cells in solution A was increased from 30 to $60 \%$, the number of entrapped cells remained constant. This would indicate that there is a

Table 1 Ethanol production, productivity, and $Y_{\mathrm{p} / \mathrm{x}}$, using beads made with different cell concentrations in solution $\mathrm{A}$

\begin{tabular}{lllll}
\hline $\begin{array}{l}\text { Sol. } \\
\text { A }(\%)\end{array}$ & $\begin{array}{l}\text { Number of cells } \\
\text { entrapped per } \\
\text { bead }\end{array}$ & $\begin{array}{l}\text { Ethanol } \\
\text { concentration } \\
(\mathrm{g} \mathrm{L}-1)\end{array}$ & $\begin{array}{l}\text { Productivity } \\
(\mathrm{g} \mathrm{L}-1 \mathrm{~h}-1)\end{array}$ & $\begin{array}{l}Y_{\mathrm{p} / \mathrm{x}} \\
\left(\mathrm{g} \mathrm{g}^{-1}\right)\end{array}$ \\
\hline 5 & $1.56 \times 10^{7}$ & $10.6 \pm 0.5$ & 3.09 & 1.492 \\
30 & $3.10 \times 10^{7}$ & $24.5 \pm 1.2$ & 7.17 & 1.711 \\
60 & $3.18 \times 10^{7}$ & $23.1 \pm 0.9$ & 7.01 & 1.651 \\
\hline
\end{tabular}


limited capacity for retaining cells [18] and this value cannot be exceeded by increasing the concentration in solution A.

It can be concluded that under the fermentation conditions implemented, there is no limitation and no cell alteration occurs as a result of the immobilization process. The beads structure is seemingly highly porous and virtually all entrapped cells participate in fermentation. This might indicate that there are no mass transfer limitations in the flow of nutrients, sugars and ethanol. In this sense, the behavior of immobilized Saccharomyces cerevisiae during carrot must fermentation (without sterilization pretreatment or addition of nutrients) would be similar to the behavior of free cells.

\section{Effect of Na-alginate concentration in solution B}

The concentration of Na-alginate in solution B is directly related to the mechanical strength of the beads. These should have adequate mechanical strength; otherwise they could break away leaking cells into the must. A too-rigid bead structure could affect both the number of immobilized cells and the transfer of nutrients and ethanol. Soft structures would not have enough mechanical strength. To study this effect, four different $\mathrm{Na}$-alginate concentrations -0.5 , 1.0, 1.5 and $2.0 \%$-were used in solution B. In each experience, a concentration of $30 \%$ yeast was used in solution A.

Results indicated that when Na-alginate concentration in solution B was $0.5 \%$, beads of varied shapes were obtained, and they had a very soft structure which easily broke into pieces. Higher concentration values of $\mathrm{Na}$ alginate-1.0 and $1.5 \%$-produced homogenous-shaped beads but with a soft and fragile structure as well. Finally, with a $2 \%$ concentration, beads had a homogenous shape with diameters of $2.0-3.5 \mathrm{~mm}$ and a hard, non-fragile structure.

Table 2 shows values corresponding to the amounts of entrapped cells before and after fermentation depending on the Na-alginate concentration in solution B. As represented in the table, before fermentation, the number of entrapped cells decreases as the concentration of Na-alginate is

Table 2 Number of cells entrapped in beads made with different alginate concentrations in solution $\mathrm{B}$, before and after fermentation

\begin{tabular}{lll}
\hline Sol. B $(\%)$ & \multicolumn{2}{l}{ Number of cells entrapped per bead } \\
\cline { 2 - 3 } & Before fermentation & After fermentation \\
\hline 0.5 & n.m. & n.m. \\
1.0 & $7.5 \times 107$ & $6.0 \times 107$ \\
1.5 & $6.1 \times 107$ & $7.1 \times 107$ \\
2.0 & $3.1 \times 107$ & $3.6 \times 107$ \\
\hline
\end{tabular}

increased. This is probably because Ca-alginate produces more bonds, so that beads are denser and stronger, and the number of retained cells is limited.

After fermentation the number of cells increased, indicating that cell growth took place inside the solid matrix. Other authors have reported that alginate beads swelled after fermentation, increasing their diameter [19]. When the concentration of alginate was 1 and $1.5 \%$, beads broke during fermentation, allowing cell leaking. Conversely, beads prepared with $2 \%$ alginate were strong enough to prevent cell leaking during the first fermentation cycle.

Summarizing, beads made with a concentration of $2 \%$ Na-alginate in solution $B$ provided the best balance between mechanical strength (to prevent cell leaking) and production of ethanol by fermentation. Similar results have been reported by Gilson and Thomas [20] and Najafpour et al. [15] who studied the effect of Na-alginate concentration on the properties of beads for fermentation. They showed that beads with low alginate concentration $(<1.5 \%)$ were too soft and easily breakable, whereas a concentration of 2-5\% Na-alginate produced beads that did not suffer any damage. Finally, beads made with Naalginate concentrations higher than $3 \%$ had a decrease in cell activity during fermentation. That decrease was caused by diffusion problems $[11,19]$. Therefore, denser beads would be less porous, and it would be more difficult for substrate diffusion to go through the beads. Thus, cells would not get enough nutrients.

\section{SEM analysis}

SEM images were taken from beads made with $2 \%$ solution $\mathrm{B}$ and $30 \%$ solution $\mathrm{A}$, before the fermentation process. Figure 1a shows the external surface and Fig. 1b shows the inner surface of the bead, with a magnification of $1,000 \mu \mathrm{m}$. The SEM images reveal that beads were densely covered with cells both inside and on the external surface, reaching the maximum capacity of entrapped yeast cells, as described in Section. "Effect of yeast concentration in solution A".

Study of external and internal mass transfer limitations

Although results obtained so far seemed to indicate that there were no mass transfer limitations, it was considered necessary to verify it systematically. The growth of cells and their metabolic activity depends on the diffusion limitations imposed by the matrix porosity and later by the impact of accumulating biomass or products in the bead surface. Cells in the center of the beads may become inactive. This can lead to the global effectiveness of immobilized cells being lower than that of a free cell system. 

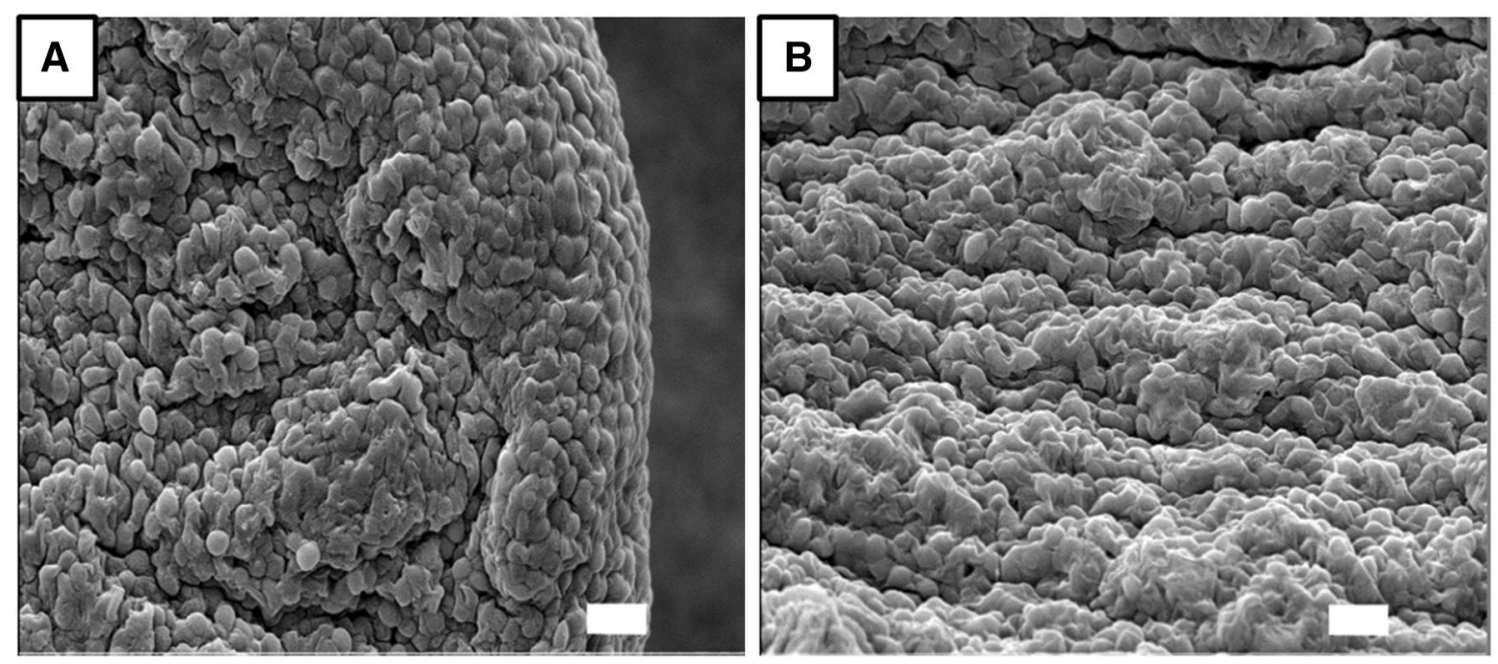

Fig. 1 Electronic micrographs of immobilized S. cerevisiae beads: (a) external surface, (b) inner surface of beads before fermentation. White bar represents $10 \mu \mathrm{m}$. Magnification: $1,000 \mu \mathrm{m}$

To evaluate the existence of internal and external mass transfer limitations, fermentation tests were performed with diverse bead diameters and varying stirring rates.

\section{Effect of stirring rate on ethanol production}

With no stirring, the beads remained at the bottom of the fermentation flask decreasing the availability of substrate for the cells. A stirring rate of $60 \mathrm{rpm}$ was found to be necessary so as to keep the beads in suspension.

To evaluate the existence of external diffusion limitations, tests using different stirring rates- $0,60,200$, and $350 \mathrm{rpm}$-were made. Figure 2 shows the pattern of ethanol concentration as a function of time for the different stirring rates.

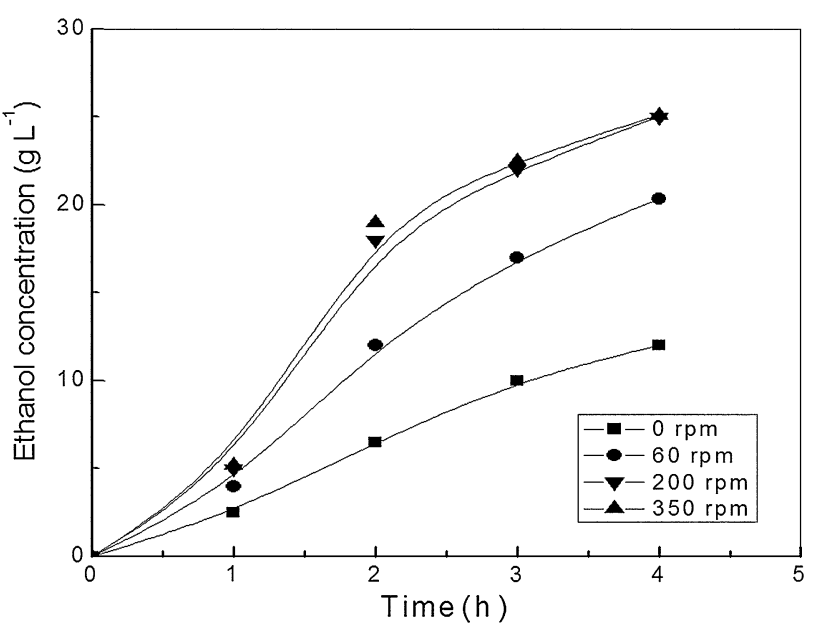

Fig. 2 Concentration of ethanol produced at any time by different stirring rates
As represented, the rate of ethanol production increased when the stirring rate is within the range $0-200 \mathrm{rpm}$, indicating the existence of external mass transfer limitations. At stirring rates faster than $200 \mathrm{rpm}$, the ethanol production rate remained constant indicating that external mass transfer limitations disappeared.

The stirring rate is an important factor that influences the ethanol yield and the fermentation rate. External mass transfer limitations disappear at stirring rates higher than $200 \mathrm{rpm}$ and ethanol production becomes dependent only on the metabolic activity of the yeasts. In this situation, nutrients have proper access to the biocatalyst and fermentation products have an adequate elution from the beads. Similar results were reported [21] during fermentation of carob pod extract using immobilized Saccharomyces cerevisiae cells in a stirred tank bioreactor.

\section{Effect of bead diameter on ethanol production}

To determine intraparticle mass transfer limitations, experiments with different initial bead diameters were performed. Beads were made as indicated in Section. "Effect of Na-alginate concentration in solution B" and then divided into two groups based on their diameter. Average values of ethanol concentration and their standard deviations, $Y_{\mathrm{p} / \mathrm{s}}$, and productivity for each group of beads are shown in Table 3.

When beads are made as described above, no significant differences in ethanol production, substrate consumption or fermentation parameters are found when using different initial bead diameters. Results suggest that there are no internal mass transfer limitations under the fermentation conditions used. This statement supports observations in Section. "Effect of yeast concentration in solution A" 
Table 3 Fermentation parameters for processes with different bead diameters

\begin{tabular}{llll}
\hline $\begin{array}{l}\text { Diameter } \\
(\mathrm{mm})\end{array}$ & $\begin{array}{l}\text { Ethanol concentration } \\
(\mathrm{g} \mathrm{L}-1)\end{array}$ & $\begin{array}{l}\mathrm{Y}_{\mathrm{p} / \mathrm{s}} \\
(\mathrm{g} g-1)\end{array}$ & $\begin{array}{l}\text { Productivity } \\
(\mathrm{g} \mathrm{L}-1 \mathrm{~h}-1)\end{array}$ \\
\hline $2.0 \pm 0.3$ & $25.7 \pm 0.6$ & 0.345 & 6.91 \\
$3.0 \pm 0.3$ & $26.6 \pm 0.5$ & 0.364 & 7.08 \\
\hline
\end{tabular}

pointing out that all retained yeast produced ethanol. Roukas [22] reported that both free and immobilized $S$. cerevisiae cells produce the same maximum ethanol concentration under the same fermentation conditions as non-sterilized carob pod extract in a batch-fed culture.

\section{Effect of initial $\mathrm{pH}$ on ethanol productivity}

Because of fermentation processes requiring living cells, different initial $\mathrm{pH}$ values should produce significant effects on ethanol yields and productivity. A study was carried out which observed the effect of initial $\mathrm{pH}$ values of $4.5 ; 5.0 ; 5.5$; and 6.4 on the ethanol concentration obtained during batch fermentation of $\mathrm{CM}$. The results of ethanol yield were $14.9 \mathrm{~g} \mathrm{~L}^{-1} ; 20.6 \mathrm{~g} \mathrm{~L}^{-1} ; 27.9 \mathrm{~g} \mathrm{~L}^{-1}$ and $25.1 \mathrm{~g} \mathrm{~L}^{-1}$, respectively. Immobilized $S$. cerevisiae were active in the range of initial $\mathrm{pH}$ values of 4.5-6.4, and achieved the maximum ethanol productivity at a $\mathrm{pH}$ of 5.5 . When initial $\mathrm{pH}$ values were lower, the ethanol production decreased. In agreement with these results, Roukas [22] reported that ethanol fermentation from carob pod extract by immobilized $S$. cerevisiae took place in the $\mathrm{pH}$ range of 3.5-6.5 and that the optimum $\mathrm{pH}$ value was 5.5.

When batch fermentation is carried out without $\mathrm{pH}$ control, $\mathrm{pH}$ decreases during fermentation, affecting the ethanol production and the productivity. During fermentation of $\mathrm{CM}$, it was generally observed that values decreased by $1.5-2 \mathrm{pH}$ units. The $\mathrm{pH}$ reduction was attributed to an increase in permeability to protons of the cytoplasmic membrane, leading to a higher consumption of ATP, thus causing an increased glycolytic activity and glucose uptake [23].

In the case of CM fermentation by free cells of S. cerevisiae, Aimaretti and Ybalo [7] reported an optimum initial $\mathrm{pH}$ value of 4.5. The difference could lie in the fact that cells are entrapped in beads which are relatively protected from alterations of the environment conditions [24].

Stability of beads in successive cycles of fermentation

Successive batch fermentation experiments were carried out to determine the stability of cells immobilized in Caalginate beads after bead reuse. Beads made with $2 \%$ solution $\mathrm{B}$ and $30 \%$ solution A were used to ferment $\mathrm{CM}$ at $30{ }^{\circ} \mathrm{C}$ with an initial $\mathrm{pH}$ of 5.5 and at a stirring rate of $200 \mathrm{rpm}$.
Figure 3 shows the results of ethanol production during the first and second fermentation cycles. It can be observed that ethanol concentration and $Y_{\mathrm{p} / \mathrm{s}}$ were higher in the second fermentation cycle-29.9 $\mathrm{g} \mathrm{L}^{-1}$ and $0.409 \mathrm{~g} \mathrm{~g}^{-1}$ as compared to the values in the first fermentation-27.1 and 0.364 , respectively. Beads reused in the second fermentation also showed an increase in productivity $(13.3 \mathrm{~g}$ $\mathrm{L}^{-1} \mathrm{~h}^{-1}$ ). This is because the lag phase time is reduced and the cell number inside beads is higher, as shown in Table 2 .

The same beads were used in three consecutive fermentation batches and differences in diameter were found. After the first fermentation, diameter increased from $2.3 \pm 0.6$ to $3.0 \pm 0.2 \mathrm{~mm}$. This is a $30 \%$ increase in bead diameter, higher than $10.5 \%$ reported by Lee et al. [19]. Diameter increase was caused by the yeast growth inside the beads (see Table 2). This was similar for all beads as it can be inferred from the small difference in the diameters.

When the second fermentation had finished, the diameter of the beads had not changed. After the third batch fermentation (results not shown) the beads began to break and cells came off. This occurs due to the high microbial load used and the cell growth. Other authors reported that beads had been used five times [19, 21].

Aimaretti et al. [8] reported that when free cells were reused, five cycles of carrot must fermentation could be performed without variations in ethanol product concentration, though with an increase in productivity. Therefore, fermentation with free cells offers the possibility of more reuse instances (more fermentation cycles) than fermentation with Ca-alginate immobilized cells. However, the cost of microbial recycling is higher than that of bead recycling. This added to the significant reduction of the cost of

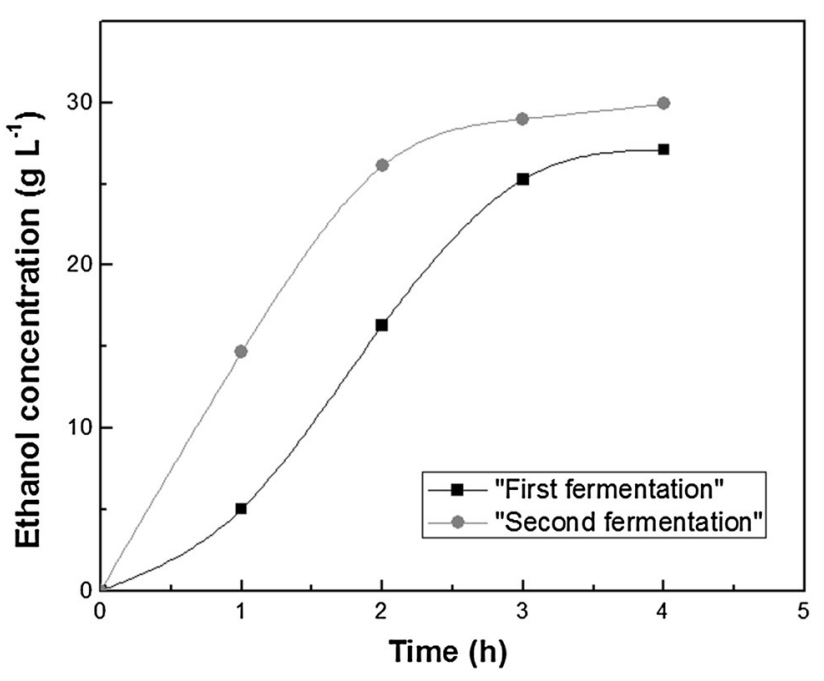

Fig. 3 Ethanol production during first and second fermentation cycles 
purification of ethanol when immobilized cells are used, points to the convenience of using immobilized biocatalyst. In fact, the use of Ca-alginate immobilized cells has several advantages, though limited mechanical stability is a problem.

The results of this report suggest that a better fermentation method would be one using beads only for three fermentation cycles and dissolving them for further bead reconstruction for the following cycles.

\section{Conclusions}

Ethanol was produced by fermentation of non-enriched and non-sterilized carrot must using immobilized yeasts. Beads made with $2 \%$ solution of Na-alginate and $30 \%$ solution of $S$. cerevisiae were strong enough to prevent cell leaking and enabled two successive fermentations. Beads permitted an efficient nutrient transfer into the matrix and a $10 \%$ yield was achieved in the second fermentation. It was found that a stirring rate of $200 \mathrm{rpm}$ was needed to prevent external mass transfer limitations. All fermentation parameters were benefited using an initial $\mathrm{pH}$ of 5.5.

Acknowledgments The authors wish to thank Emilce Llopart, Marianela Lostumbo, Melina Appendino and María Cecilia Bianco for their valuable cooperation. This work was carried out with the financial support of Project ALI 127 developed by the Latin American Educational Centre University (UCEL) and PIP 0398 by CONICET (Argentina).

Conflict of interest The authors declare that they have no conflict of interest.

Open Access This article is distributed under the terms of the Creative Commons Attribution License which permits any use, distribution, and reproduction in any medium, provided the original author(s) and the source are credited.

\section{References}

1. Ghorbani, F., Younesi, H., Esmaeili Sari, A., Najafpour, G.: Cane molasses fermentation for continuous ethanol production in an immobilized cells reactor by Saccharomyces cerevisiae. Renew. Energy. 36, 503-509 (2011)

2. Cardona, C., Sánchez, O.: Fuel ethanol production: process design trends and integration opportunities. Bioresour. Technol. 98, 2415-2457 (2007)

3. Talebnia, F., Karakashev, D., Angelidaki, I.: Production of bioethanol from wheat straw: an overview on pretreatment, hydrolysis and fermentation. Bioresour. Technol. 101, 4744-4753 (2010)

4. Brethauer, S., Wyman, C.E.: Review: continuous hydrolysis and fermentation for cellulosic ethanol production. Bioresour. Technol. 101, 4862-4874 (2010)

5. González-García, S., Gasol, C., Gabarrell, X., Rieradevall, J., Moreira, M.T., Feijoo, G.: Environmental aspects of ethanolbased fuels from Brassica carinata: a case study of second generation ethanol. Renew. Sustainable. Energy. Revi. 13, 2613-2620 (2009)

6. Aimaretti, N., Ybalo, C., Rojas, M.L., Plou, F.J., Yori, J.C.: Production of bioethanol from carrot discards. Bioresour. Technol. 123, 727-732 (2012)

7. Aimaretti, N., Ybalo, C.: Valorization of carrot and yeast discards for the obtention of ethanol. Biomass. Bioenerg. 42, 18-23 (2012)

8. Aimaretti, N., Clementz, A., Codevilla, A., Rojas, M.L., Yori, J.C.: Sustainable fermentation processing of two revalorized agro-industrial discards: carrot and brewer's yeast. Int. J. of Energy Environ. Eng. 4 24, 1-7 (2013)

9. Vasconcelos, J.N., Lopes, C.E., Franca, F.P.: Continuous ethanol production using yeast immobilized on sugar-cane stalks. Braz. J. Chem. Eng. 21, 357-365 (2004)

10. Draget, K.I., Skjak-Brak, G., Smidsrod, O.: Alginate based new materials. Int. J. Biol. Macromol. 21, 47-55 (1997)

11. Idris, A., Suzana, W.: Effect of sodium alginate concentration, bead diameter, initial $\mathrm{pH}$ and temperature on lactic acid production from pineapple waste using immobilized Lactobacillus delbrueckii. Process. Biochem. 41, 1117-1123 (2006)

12. Yan, J., Bajpai, R., Iannoti, E., Popovic, M., Mueller, R.: Lactic acid fermentation from enzyme-thinned starch with immobilized Lactobacillus amylovorus. J. Chem. Biochem. Eng. 15(2), 59-63 (2001)

13. Carvalho, W., Silva, S.S., Santos, J.C., Converti, A.: Kylitol production by $\mathrm{Ca}$ alginate entrapped cells: comparison of different fermentation systems. Enzyme Microb. Technol. 32, 553-559 (2003)

14. Prasad, B., Mishra, I.M.: On the kinetics and effectiveness of Immobilized whole cell batch cultures. J. Bioresour. Technol. 53, 269-275 (1995)

15. Najafpour, G., Younesi, H., Ku Ismail, K.S.: Ethanol fermentation in an immobilized cell reactor using Saccharomyces cerevisiae. Bioresour. Technol. 92(3), 251-260 (2004)

16. Yu, J., Zhang, X., Tan, T.: Optimization of media conditions for the production of ethanol from sweet sorghum juice by immobilized Saccharomyces cerevisiae. Biomass. Bioenerg. 33, 521-526 (2004)

17. Colin, R., Bjorn, K.: Basic biotechnology, 2nd edn. Cambridge University Press, Cambridge (2002)

18. Park, J.K., Chang, H.N.: Microencapsulation of microbial cells. Biotechnol. Advances. 18, 303-319 (2000)

19. Lee, K.H., Choi, I.S., Kim, Y.-G., Yang, D.-J., Bae, H.-J.: Enhanced production of bioethanol and ultrastructural characteristics of reused Saccharomyces cerevisiae immobilized calcium alginate beads. Bioresour. Technol. 102, 8191-8198 (2011)

20. Gilson, C.D., Thomas, A.: Ethanol production by alginate immobilized yeast in a fluidized bed bioreactor. J. Chem. Technol. Biotechnol. 62, 38-45 (1995)

21. Ercan, Y., Irfan, T., Mustafa, K.: Optimization of ethanol production from carob pod extract using immobilized Saccharomyces cerevisiae cells in a stirred tank bioreactor. Bioresour. Technol. 135, 365-371 (2013)

22. Roukas, T.: Continuous ethanol production from carob pod extract by immobilized Saccharomyces cerevisiae in a packedbed reactor. J. Chem. Technol. Biotechnol. 59, 387-393 (1994)

23. Kourkoutas, Y., Bekatorou, A., Banat, I.M., Marchant, R., Koutinas, A.: Immobilization technologies and support materials suitable inalcohol beverages production: a review. Food Microbiol. 21, 377-397 (2004)

24. Buzas, Z., Dallmann, K., Szajani, B.: Influence of $\mathrm{pH}$ on the growth and ethanol production of free and immobilized $S a c$ charomyces cerevisiae cells. Biotechnol. Bioeng. 34, 882-884 (1989) 